\title{
A Painful Gluteal Mass
}

\section{Tobe Momah MD, MSc, Van-Vi, Le, MD, Kelsey, Thomas, MD}

Assistant Professor, Department of Family Medicine, University of Mississippi Medical Center 764 Lakeland Drive Jackson MS 39216, USA.

*Corresponding Author: Tobe Momah MD, MSc, Assistant Professor, Department of Family Medicine, University of Mississippi Medical Center 764 Lakeland Drive Jackson MS 39216, USA.

\section{CASE REPORT}

A 59 year old African American male with past medical history of hypertension, hyperlipidemia, cerebrovascular accident, and nicotine dependence (47-pack-years) presented to the emergency room (ER) for complaints of left gluteal mass for two months. The mass was associated with a dull, aching pain, and was progressively increasing in size.

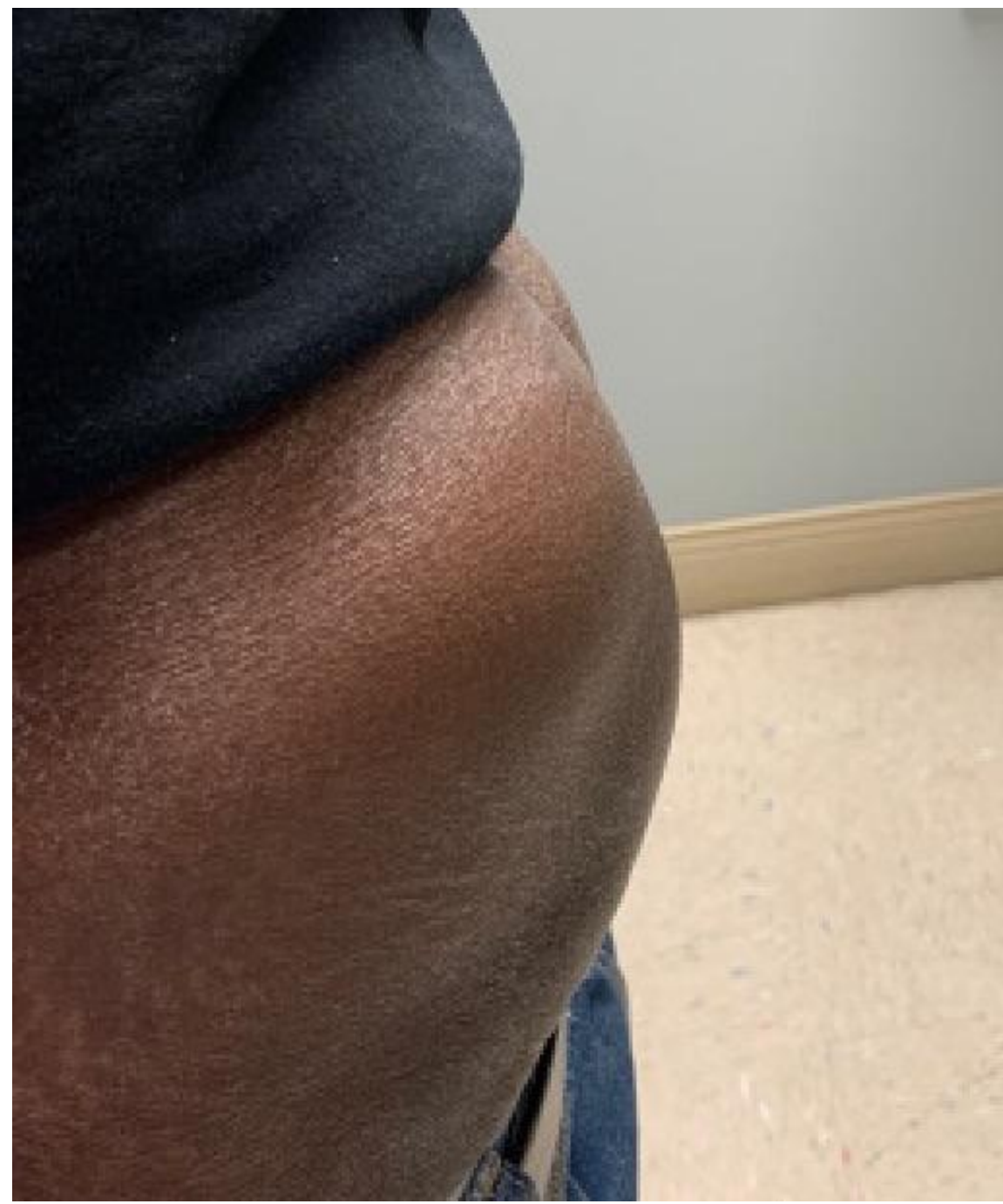

Physical exam was remarkable for cervical lymphadenopathy and a $5 \times 6 \mathrm{~cm}$ firm, nonfluctuating mass on the left gluteal region (figure 1). Patient had triedantibiotics and pain medications from another provider but the mass had only enlarged. A computerized tomography (CT) scan of the pelvis in the ER demonstrated a $6.5 \times 3.5 \times 4.7 \mathrm{~cm}$ oval mass in the left gluteus maximus muscle and a $2.1 \times 2.5 \mathrm{~cm}$ expansile lytic lesion in the anterior left iliac bone (figure 2). 


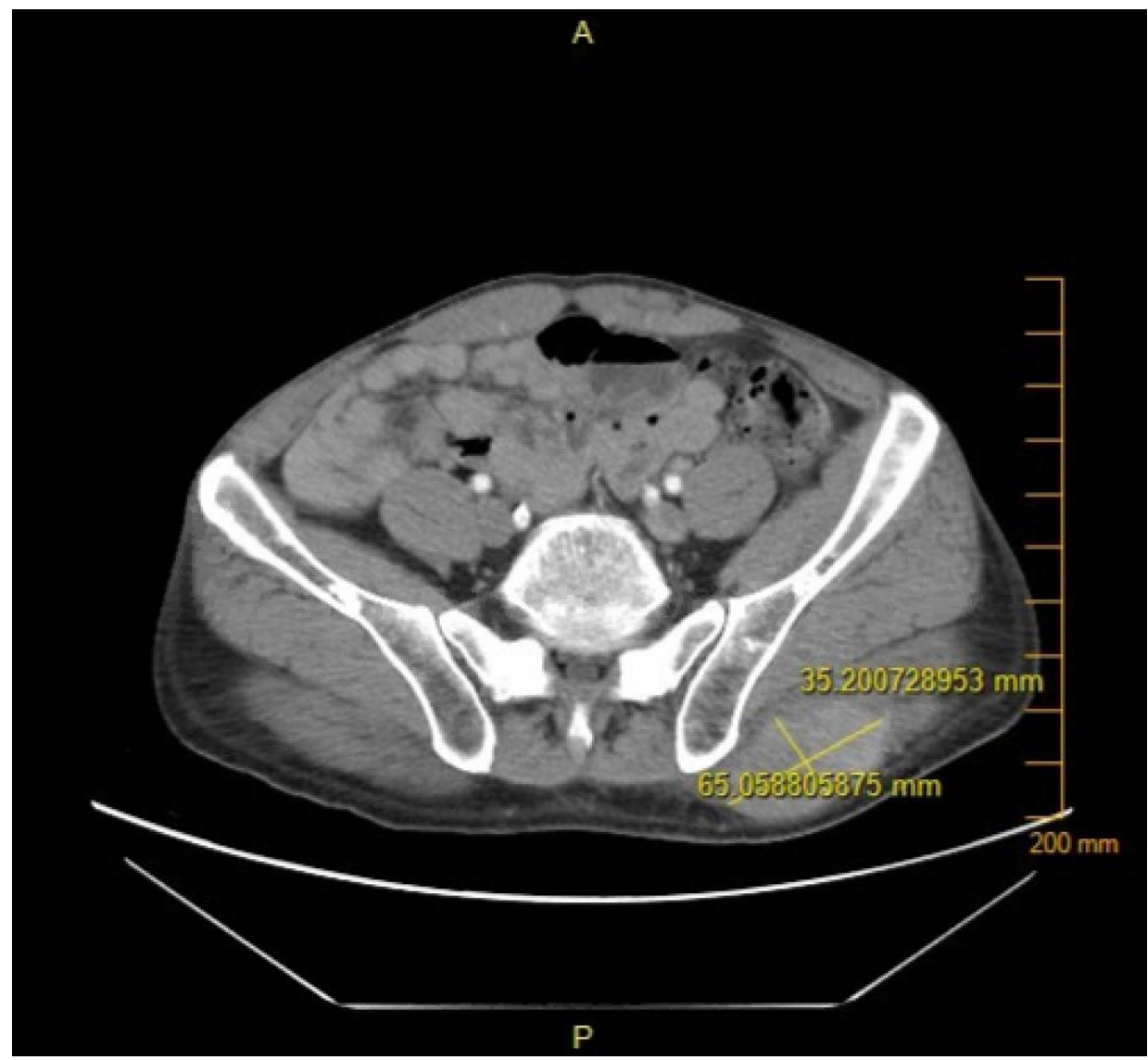

Patient was admitted to hospital, and had a CT chest and abdomen with contrast which revealed a $2.8 \times 2.8 \mathrm{~cm}$ left upper lobe mass (figure 3 ). $\mathrm{He}$ was then scheduled for an outpatient ultrasound-guided needle biopsy of the left gluteal mass. Based on the patient's history and physical examination, which one of the following is the most likely diagnosis?

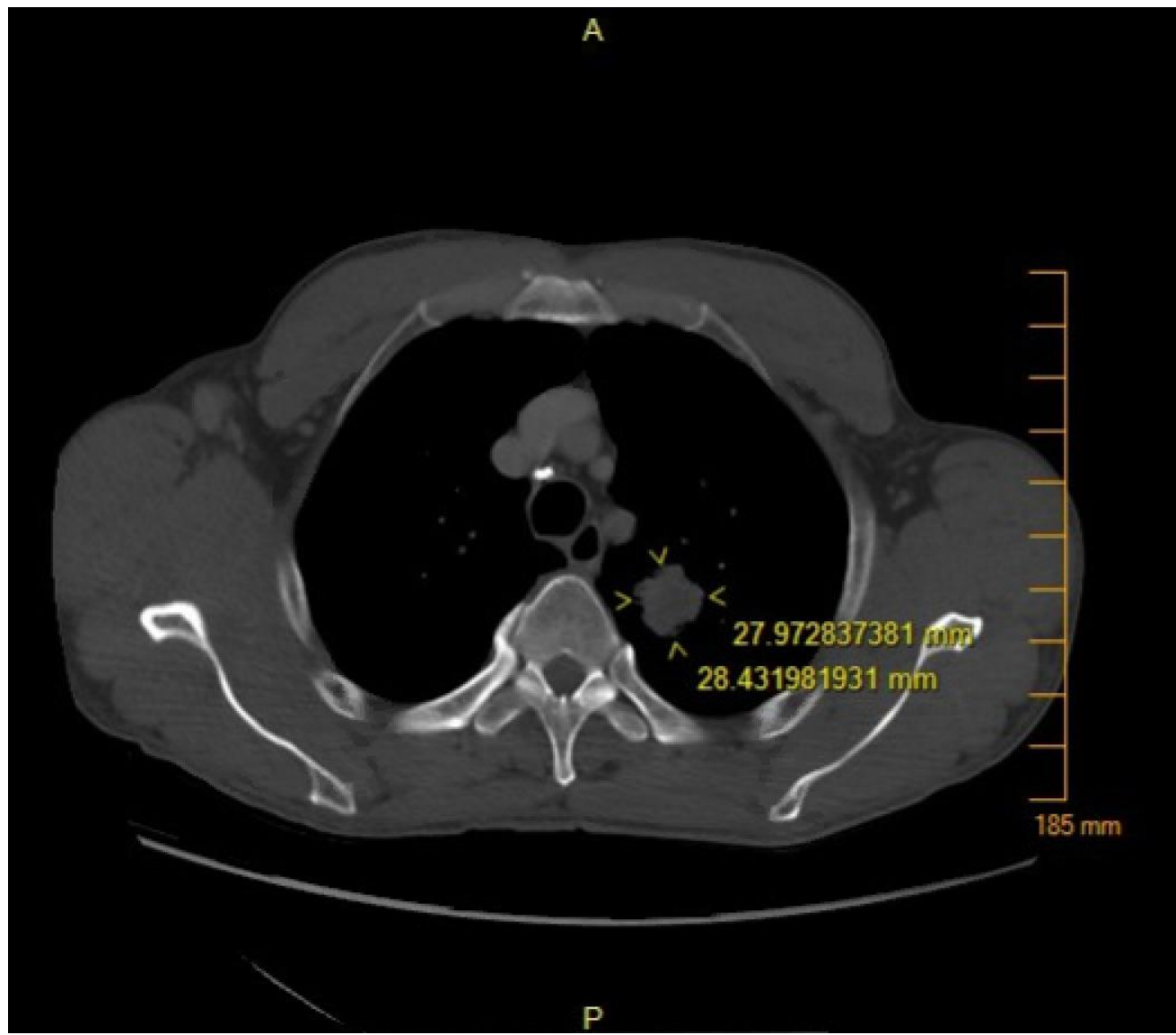


A. Metastatic lung cancer to the left gluteus maximus muscle

B. Left Intramuscular Gluteal Abscess

C. Liposarcoma of Gluteal muscle

\begin{tabular}{|l|l|}
\hline \multicolumn{2}{|c|}{ Selected Differential Diagnosis of Abnormal EKG changes in hypothermia (Osborne Waves) } \\
\hline \multicolumn{1}{|c|}{ Condition } & \multicolumn{1}{c|}{ Characteristics } \\
\hline $\begin{array}{l}\text { Metastatic lung mass to left gluteus } \\
\text { Maximus muscle }\end{array}$ & $\begin{array}{l}\text { Rare site of metastases, but mostly seen in nicotine users and associated } \\
\text { with firmness, regional lymphadenopathy and pain. }\end{array}$ \\
\hline Liposarcoma & $\begin{array}{l}\text { Seen in elderly patients, and more common in lower extremities. } \\
\text { Typically non tender nor erythematous in the early stages of } \\
\text { presentation. }\end{array}$ \\
\hline Left intramuscular Gluteal abscess & $\begin{array}{l}\text { Characterized by inflammation and a collection of pus with associated } \\
\text { tenderness, redness, warmth and swelling in gluteal region. }\end{array}$ \\
\hline
\end{tabular}

\section{DISCUSSION}

The correct answer is A.

Lung cancer is still the number one cause of deaths worldwide. ${ }^{1}$ The majority of these patients $(85 \%)$ are diagnosed with non-small cell lung cancer (NSCLC) with the most common metastatic sites from NSCLC including lung, bone, brain, adrenal glands, and liver. ${ }^{2}$ Metastases to the soft tissue, especially the buttock, are rare but documented. ${ }^{3}$

Our patient's histopathology showed cohesive groups of pleomorphic tumor cells strongly positive for $\mathrm{CK} 7$, weakly positive for CDX2, and negative for CK20, CK5/6, P63, PSA and TTF-1. He was subsequently diagnosed with metastatic high-grade carcinoma most likely from poorly differentiated squamous cell carcinoma of the lung.

An intramuscular gluteal abscess is an intramuscular soft tissue lesion of the gluteal region characterized by inflammation and the collection of pus, often at the site of intramuscular injections. ${ }^{4}$ Signs and symptoms include tenderness, warmth, pain, erythema, and swelling. Our patient had a non-erythematous mass and no obvious sign of infection.

Liposarcoma presents as well differentiated Liposarcoma (WDL) or Dedifferentiated Liposarcoma (DDL), ${ }^{5}$ and is more common in lower extremities. It, however, initially presents as a soft, painless subcutaneous nodules ranging between 1 to $10 \mathrm{~cm}$ that has persisted for years. Our patient had no prior history of such swellings his mass was painful at initial presentation, which is uncharacteristic of lipoma.

\section{REFERENCES}

[1] Molina J, Yang P, Cassivi S, Schild S, Adjei A, Divaolu M, Shaub T, Firstenberg M. NonSmall Cell Lung Cancer: Epidemiology, Risk Factors, Treatment, and Survivorship. Mayo Clin Proc. 2008 May; 83(5): 584-594. doi: 10.4065/83.5.584.

[2] Niu F-Y, Zhou Q, Yang J-J, et al. Distribution and prognosis of uncommon metastases from non-small cell lung cancer. Bmc cancer. 2016;16(1). doi:10.1186/s12885-016-2169-5

[3] Al-Alao BS, Westrup J, Shuhaibar MN. Nonsmall-cell lung cancer: unusual presentation in the gluteal muscle. General thoracic and cardiovascular surgery. 2011;59(5):382-384. doi:10.1007/s11748-010-0670-3

[4] McIvor A, Paluzzi M, Meguid MM. Intramuscular injection abscess--past lessons relearned. N Engl J Med. 1991 Jun 27; 324 (26) :1897-8. PubMed ID: 2041559

[5] Khin T. Well-differentiated liposarcoma and dedifferentiated liposarcoma: An updated review. Semin Diagn Pathol. . 2019 Mar; 36(2) [1]:112-121. doi:10.1053/j.semdp.2019.02. 006. Epub 2019 Feb 28.

Citation: Tobe Momah et.al, "A Painful Gluteal Mass", International Journal of Research Studies in Medical and Health Sciences. 2020; 5(12): 24-26.

Copyright: (c) 2020 Tobe Momah et.al, This is an open-access article distributed under the terms of the Creative Commons Attribution License, which permits unrestricted use, distribution, and reproduction in any medium, provided the original author and source are credited. 